\title{
Invisible Women: Altered Female Bodies
}

In I7 I I, William Beckett, a well-respected surgeon, provided the readers of his New Discoveries Relating to the Cure of Cancers with instructions for performing a mastectomy operation:

Let the Patient be placed in a clear Light, and held steady; then take hold of the Breast with one hand, and pull it to you; and, with the other, nimbly make Incision, and cut it off as close to the Ribs as possible, that no Parts of it remain behind. But if any cancerous Gland should remain, be sure to have actual Cauteries of different sizes, ready hot by you, to consume it, and to stop the Bleeding; or otherwise apply, for restraining the Hemorrhage, Dorsels dipp'd in scalding hot Ol. Terebinth [turpentine oil] ... then with good Boulstring and Rolling, conveniently place the Patient in Bed, and at night give her an anodine Draught, then the second or third Day open it, digest, deterge, incarn and siccatrize. ${ }^{\mathrm{I}}$

Though the procedure was a grim one, Beckett knew more about treating cancer than almost any of his contemporaries, and his instructions represented best practice for an aspiring surgeon. In one respect, however, Beckett's account - and his entire text - was lacking. Neither this, nor any other account of mastectomy which I have found, mentions what happened to the patient after they healed. ${ }^{2}$ This is in stark contrast to other kinds of body-altering operations which I describe in this book. There was, as Chapter 4 explores, a rich discourse about prostheses for limb amputees and their functionality. As Chapter 3 shows, descriptions of facial surgery and prostheses emphasised the

\footnotetext{
${ }^{1}$ William Beckett, New Discoveries Relating to the Cure of Cancers, Wherein a Method of Dissolving the Cancerous Substance Is Recommended, with Various Instances of the Author's Success in Such Practice, on Persons Reputed Incurable, in a Letter to a Friend. To Which Is Added, a Solution of Some Curious Problems, Concerning the Same Disease (London, I7I I), pp. 69-70.

2 See Alanna Skuse, Constructions of Cancer in Early Modern England: Ravenous Natures (Basingstoke: Palgrave Macmillan, 2015).
} 
social rehabilitation of patients. When it came to mastectomy survivors, however, there were no such descriptions, no mentions of padding or prostheses to replace the lost breast, and no clues about whether women with one breast went on to have more children, to marry or remarry, or to work. In this chapter, I will argue that women whose bodies were altered by surgery became invisible in early modern texts, and will explore why this might be the case.

In many ways, the sexually altered female bodies which I will describe here are correlates to the castrato body discussed in the previous chapter. Both were exoticised and often dehumanised, and in both cases, contemporary texts demonstrated a fascination with the (dis) abilities which such bodily alterations might confer. However, where the castrato body was hypervisible and overdetermined (notwithstanding the determined lack of attention paid to castrati's own experiences), the altered female body was underdetermined, and viewed only within specific textual contexts. Ethnography provided a space within which the phenomenological implications of altering the female body might be explored. However, such bodies were kept at arm's length. The combination of femininity and disability was a disturbing, ultimately abject prospect.

\section{Altering the Female Body}

The main sex-specific way in which the female body was surgically changed in the early modern period was by mastectomy, the removal of the breast, in whole or part, usually as a treatment for cancer. ${ }^{3}$ Such surgeries have often been overlooked by medical historians, who have understandably assumed that these operations were too dangerous to have been attempted on any regular basis. Removing a breast to treat a slowly spreading cancer was, after all, a quite different prospect to amputating a limb which was mangled beyond repair and bleeding dangerously; the former required a prior commitment to excruciating pain and danger which is now almost unthinkable. Nonetheless, as this book discusses elsewhere, early modern people were, remarkably, prepared to undergo non-emergency surgeries in order to secure both longevity and quality of life. This was particularly the case for women facing cancer, a disease feared by patients and physicians alike, and

3 Ibid. 
known to cause a slow, agonising death if left untreated. As the French surgeon Pierre Dionis put it:

If we believe Hippocrates, Cancers are not to be touch'd, for in touching them, observes that Author, you aggravate the Evil, and hasten the Death of the Patient.

But how are you to resist the Persecutions of a poor suffering Patient, which implores your help? Are you to abandon her to the Rigour of her Distemper, which torments her Day and Night? No, a Chirurgeon must not be so cruel: He must search out Means to cure her. ${ }^{4}$

Mastectomy was, therefore, a recognised part of the surgical repertoire: though not common, it was an option available to most experienced surgeons. Methods for the operation are detailed in numerous prominent medical textbooks, including those by Richard Wiseman, James Cooke, and William Salmon. ${ }^{5}$ They usually follow a similar method to that described by Beckett above. The breast was cut around the base, most commonly with a knife similar to that used in limb amputations, but sometimes with a sharp wire. With the breast removed, the surgeon would attempt to remove any tumour that remained visible, either by excision or using a hot iron cautery. They then used cautery or styptic powders to stem the flow of blood, before dressing the wound and hoping for the best. As is often the case for this period, what we know of patient experiences of this procedure is pieced together from second-hand accounts. There are no autobiographical accounts from this period from women who underwent mastectomies - the first known example is Frances Burney's evocative description of her mastectomy in $18 \mathrm{II}^{6}{ }^{6}$ It is abundantly clear, however, that such surgeries were immensely traumatic for everybody involved. Many surgeons admitted that they dreaded these operations, during which the life of the patient and the reputation of the practitioner were in imminent danger, and in which the suffering of the patient could disturb even a hardened operator. One Medical Dictionary advised readers that

\footnotetext{
${ }^{4}$ Pierre Dionis, A Course of Chirurgical Operations, Demonstrated in the Royal Garden at Paris. By Monsieur Dionis, Chief Chirurgeon to the Late Dauphiness, and to the Present Dutchess of Burgundy. Translated from the Paris Edition (London, I7 I0), pp. 249-50.

5 Richard Wiseman, Several Chirurgical Treatises (London, I686), pp. I08-Io; James Cooke, Mellificium Chirurgia, or the Marrow of Many Good Authors Enlarged: Wherein Is Briefly, Fully, and Faithfully Handled the Art of Chirurgery in Its Four Parts, with All the Several Diseases unto Them Belonging: Their Definitions, Causes, Signes, Prognosticks, and Cures, Both General and Particular (London: printed by T.R. for John Sherley, I662), pp. 308-I2; William Salmon, Ars Chirurgica (London, I698), p. 98.

${ }^{6}$ Frances Burney, 'Letter from Frances Burney to Her Sister Esther about Her Mastectomy without Anaesthetic, I8I2' (Paris, I8I2), Berg Coll. MSS Arblay, British Library.
} 
women undergoing mastectomy might 'shriek and cry in a manner so terrible, as is sufficient to shock and confuse the most intrepid surgeon, and disconcert him in his operation'?

Notwithstanding the evident sympathy many surgeons had for their patients, however, medical accounts of mastectomy also show that these operations were an exercise in which groups of professional men exerted their power to control the female body, even to the extent of granting life or death. ${ }^{8}$ As was the case for castrati, this dynamic was manifested in texts' inattention to the phenomenological experience of the person whose ordeal they described, either from a somatic or a psychological perspective. Accounts of cancer surgery in medical textbooks sometimes talk in detail about the symptoms and living situation of the patient prior to surgery; as I discuss below, cancer was linked to a number of causes including mastitis and amenorrhea. In descriptions of the mastectomy itself, however, the subjectivity of the patient is pointedly erased. By their own admission, surgeons operated not on a person, but on a breast, assiduously seeking to 'devide the good from the evill'. ' As this book will demonstrate at various points, there was a general tendency in early modern accounts of surgery to objectify the person under the knife. In cases of mastectomy, however, this tendency seems to be have been amplified. Dionis, for instance, assured the readers of his Chirurgical Operations that ' $\mathrm{t}$ ]his Operation is easier than is imagined before 'tis performed; for the Breast separates as easily from the Ribs, as when we divide the Shoulder from a Quarter of Lamb'. ${ }^{\circ}$

This impulse to deny both the psychological and physical experiences of mastectomy patients extended beyond the operation itself. Moreover, this is not only an effect of scarcity of evidence. Mastectomy surgeries were less common than (for example) limb amputations, but there is evidence that they were taking place semi-regularly throughout the seventeenth and eighteenth centuries. From the I700s, newspapers reported the operations of the great and good: on 8 February I728, for instance, an announcement in the London Evening Post reported that 'the lady of Sir Challenor Ogle'

7 Robert James, 'Amputation', in A Medicinal Dictionary, 3 vols. (London, I743), vol. I, sig. 5GV.

${ }^{8}$ As I have observed elsewhere, cancer surgeries, being relatively unusual, tended to attract students and other observers. For instance, Richard Wiseman recorded operating on cancers alongside or in front of other professionals including including Walter Needham, 'Mr Nurse', Doctor Bate, Doctor Thomas Cox, Doctor Micklethwaite, Jacques Wiseman (his 'kinsman'), and Mr Hollier, Mr Arris, Edward Molin, Mr Troutbeck, and Mr Shunbub (all chirurgeons). Wiseman, Several Chirurgical Treatises, pp. IоI-2.

9 Philip Barrough, The Method of Physick (London, I583), p. 232; see also Johannes Scultetus, The Chyrurgeons Store-House, trans. E.B. (London: printed for John Starkey, I674), p. I7I.

Io Dionis, Chirurgical Operations, pp. 254-5. 
had undergone an operation to remove a cancer in her breast, 'and there is great Hopes of her Recovery'. ${ }^{\text {II }}$ The obituary pages also recorded the deaths of numerous women during or shortly after surgery. ${ }^{\mathrm{I2}}$ However, despite the fact that mastectomy survivors existed, they are virtually invisible in the historical record. Medical texts may detail the dressings and medicines used in the days and weeks after surgery, but they end abruptly thereafter. This is a stark contrast to narratives of limb amputation described in Chapter 4, which emphasise return to functionality as part of the recovery narrative. Neither do mastectomy survivors appear in the popular texts which valorised, demonised, mocked, and sympathised with other kinds of 'altered bodies'. In short, they are conspicuous by their absence.

\section{Amazons}

In one arena, however, the effects of mastectomy were being discussed. As colonial activity burgeoned in the sixteenth and seventeenth centuries, lurid tales reached England of unimammarian women living in remote parts of the world, often in gynocentric societies. Such accounts often blended mythology, history, and ethnography, and could be found in a variety of texts. From the fourteenth century, manuscript copies of Sir John Mandeville's Voyages and Travailes circulated in French, and later in English translations and editions, including a printed edition in $1582 .{ }^{13}$ John Bulwer's Anthropometamorphosis (published in 1650 and in an enlarged edition in 1653) featured a comprehensive catalogue of human variation and bodily modification, which included Amazons. ${ }^{14}$ Likewise, Thomas Heywood's I624 Gynaikeion sought to provide a 'history of women' arranged under the names of the nine classical muses. Throughout these varied reports, however, the main features of Amazons and Amazon society remained the same. Most authors agreed that the Amazons were an ancient society, though their exact origins, and their current geographical location, were confused. Prose histories of the

I London Evening Post, 8 February I728.

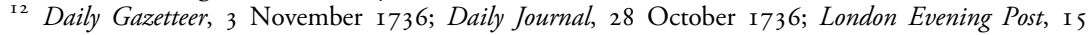
February I729.

${ }^{13}$ John Mandeville, The Voyages and Trauailes of Sir John Maundeuile Knight Wherein Is Treated of the Way towards Hierusalem, and of the Meruailes of Inde, with Other Lands and Countries (London: printed by Thomas Este, I 582), sig. L2r-v.

I4 John Bulwer, Anthropometamorphosis: = Man Transform'd: Or, the Artificiall Changling (London: printed by William Hunt, I653), pp. 32I-5. 
seventeenth century repeatedly asserted that the Amazons were an offshoot of the Scythian people. Heywood, for instance, attested that the Amazons were originally Scythian women who migrated while their husbands were away at war and formed their own society, while others believed that the Amazons warred with the Scythians or bore children by them. ${ }^{\text {Is }}$ Many texts drew on the works of Plutarch and Virgil, in which numerous stories circulate of couplings between Western heroes and Amazonian princesses. In some versions, Theseus abducts and then marries Antiope, sister of the Amazonian queen Hippolyta; in others, he weds Hippolyta herself. ${ }^{16}$ Alexander the Great was also reputed to have been visited by and fathered a child with the Amazon queen Thalestris. ${ }^{17}$

Whatever their origins, authors were clear that Amazons lived either entirely without men, or with men in subservient roles. In 1582 , for instance, Mandeville's Voyages and Travailes was printed and described (with considerable imaginative licence) how a New World tribe of warrior women would 'suffer no men to live among them, nor to have rule over them', instead periodically inviting men to copulate with them. ${ }^{18}$ Fourteen years after Mandeville's account appeared in print, Sir Walter Raleigh published his own, more detailed version of the Amazon story as part of the Discovery of the Large, Rich, and Beautiful Empire of Guiana. It stated confidently that Guianese Amazons partnered with local kings for one month each year, during which they would 'feast, daunce, and drinke of their wines in abundance, and the Moone being done, they all depart to their owne Provinces'. Moreover,

It was farther told me, that if in the wars they tooke any prisoners that they used to accompany with those also at what time soever, but in the end, for certaine they put them to death: for they are said to be very cruell and bloodthirsty, especially to such as offer to invade their territories. ${ }^{19}$

Amazons' famously ferocious and gynocentric societies were closely indexed to their most distinctive bodily feature: the removal of one breast. Though Raleigh noted that 'that they cut offf] the right dug of the brest

I5 Thomas Heywood, Gynaikeion: Or, Nine Bookes of Various History. Concerninge Women Inscribed by Ye Names of Ye Nine Muses (London, I624), 220; Gaultier de Coste La Calprenède, Hymen's Praludia, or Loves Master-Peice Being That so Much Admired Romance, Intituled Cleopatra: In Twelve Parts (London: W.R. and J.R, I674), p. I59.

${ }^{16}$ Plutarch, Plutarch's Lives. (London: Jacob Tonson, I683), pp. 40-I.

${ }_{17}$ Heywood, Gynaikeion, p. 222.

${ }^{18}$ Mandeville The Voyages and Trauailes of Sir John Maundeuile, sig. L3r.

19 Walter Raleigh, Discovery of the Large, Rich, and Beautiful Empire of Guiana, by Sir W. Ralegh: With a Relation of the Great and Golden City of Manoa (Which the Spaniards Call El Dorado), Etc. (I596) (London: Hakluyt Society, I848), pp. 27-9. 
I do not finde to be true', most other accounts disagreed. ${ }^{20}$ Mandeville specified that Amazon girls of noble birth had the left breast removed by cautery to allow them to better bear a shield, while ordinary girls had the right breast removed to befit them for a bow and arrow. ${ }^{2 \mathrm{I}}$ Heywood asserted that 'the right brest they burne off, that with the more facilitie they may draw a Bowe, thrill a Dart, or charge a Launce'. ${ }^{22}$ Meanwhile, Bulwer argued that there existed a number of different Amazonian tribes, among whom breast removal was a common practice:

The Ancient Amazones, of whom we read so oft in learned Authors, were wont to seare off their right breasts, which was then the archers fashion. Porta saies, the Amazons sear off their right paps, that more nourishment going into the hand next to it, might increase the strength of that which was but weake by nature. Others say, that the Amazons much helping themselves in the wars with bows and arrows, and finding that in this and other exercises of armes their dugs or breasts were a very great hinderance to them, they used to burne off the right pap, both of themselves and their daughters, and thereupon they were called Amazons, which signifieth in the Greeke tongue, No Breasts.

The chiefe of the guard of the King of Congo are lefthanded Amazons, who seare off their left paps with a hot iron, because it should be no hinderance to them in their shooting. ${ }^{23}$

All these reports had in common a fascination with the anomalous body of the Amazon, akin to that which characterised reports of castrato bodies. Here, as there, bodily difference was bound up with racial Otherness, and both had potential to titillate. It was no coincidence that Bulwer's and Mandeville's texts both contained pictures of Amazon women with their chests partially or fully exposed. Heywood's text similarly teased readers with its description of Amazon dress: 'Their garments cover not their bodies round; their right side is still bare towards their brest; their upper roabe which is buckled or buttoned above, descends no lower than the knee. ${ }^{24}$ In such discourse, Amazons were both objects of lust and causes for fear. While procreative, they evaded the structures of marriage and patriarchy, and engaged in sex for pleasure as well as for reproduction. Moreover, unlike other sexually promiscuous female figures, the Amazon could not be stereotyped as a prostitute; as Simon Shepherd acknowledges, ' $t]$ he propertied Amazon cannot be cast aside, as would a whore. And she

${ }^{20}$ Ibid. $\quad{ }^{2 \mathrm{I}}$ Mandeville, The Voyages and Trauailes of Sir John Maundeuile, sig. L2v.

${ }_{22}$ Heywood, Gynaikeion, p. $223 .{ }_{23}$ Bulwer, Anthropometamorphosis, pp. 32 I-2.

24 Heywood, Gynaikeion, p. 223. 
imitates men in using social power for sexual exploitation. Hence the nightmarish turning of the tables. ${ }^{25}$ Instead, Amazon women were understood to use their bodies and exercise their sexuality in ways which were not easily defined. In Kathryn Schwarz's insightful Tough Love: Amazon Encounters in the English Renaissance, she shows how Amazon stories influenced representations of contemporary femininity, including depictions of Elizabeth I. Often, argues Schwarz, stories about Amazons envision them becoming domesticated, turned into obedient wives and mothers. Yet their attraction remains in their 'queerness', an alterity of desire which reveals rigid heterosexual and homosocial structures as cultural rather than natural.

'Amazon' cannot signify in any singular or straightforward way ... Bringing them close to home invites chaos: as separatists they are a threat, but as mothers and lovers and wives and queens they are a disaster, participating in and altering the structures that should work to keep them out. Yet even as texts from this period locate the alien within the familiar, they suggest the sense in which that process is already redundant: in representations of Amazons as in representations of women and men, challenges to conventional identities and hierarchies are at least as familiar as conventions themselves. The imaginative power of domestic Amazons lies not only in the inherent perversity of the term, but in its exposure of the incongruities that underlie social and sexual acts. ${ }^{26}$

As Schwarz shows, the underdetermination of Amazons in terms of location and origins allowed them to embody a range of anxieties around homosociality, gender roles, and sexual desire. Looking at the Amazon body through the lens of early modern surgery raises other questions namely, can we also consider these bodies as doing cultural work which extended to early modern survivors of mastectomy? The repudiation of heteronormative structures and of traditional motherhood implicit in the Amazons' self-alteration speaks in unexpected ways to discourses about cancer and mastectomy, in which images of maternity were omnipresent. As I have described elsewhere, cancer was believed to be far more common in women than in men, with diagnoses of breast cancer far outstripping all others. The language in which cancerous growth was described often mirrored that used about foetuses: each drew nourishment from the woman's body, and was 'delivered' with much pain and hazard. In practical terms too, maternity and cancer were close companions. Cancer was

25 Simon Shepherd, Amazons and Warrior Women: Varieties of Feminism in Seventeenth-Century Drama (Brighton: Prentice Hall/Harvester Wheatsheaf, I981), pp. I6-I7.

${ }^{26}$ Kathryn Schwarz, Tough Love: Amazon Encounters in the English Renaissance (Fordham: Duke University Press, 2000), p. 23. 
often believed to have its origins in 'burnt' humours concocted in the womb, particularly when the menses were stopped. ${ }^{27}$ This was thought to be a decisive factor in the high incidence of cancers in post-menopausal women. Even more commonly, tumours were thought to start with mastitis, which in turn could be caused by problems with breastfeeding, or by not breastfeeding. ${ }^{28}$

The possible extent of linkage between Amazonian and medical mastectomy is apparent in pictorial representations of both phenomena. Figure 2.I, for instance, shows Amazons as they are represented in Bulwer's Anthropometamorphosis. The images are remarkable in several respects. They pointedly show the healthy breast alongside the missing one, and relegate the wound left by amputation to a linear scar. Attention is further diverted from this scar by the figures' lavishly draped clothing, jewellery, and weaponry, all of which attest to the Amazons' status as at once warlike and feminine. Moreover, the images are double: both the removal of the left and of the right breast are shown, despite the limited educational utility of this repetition. We may usefully compare these images to Figure 2.2, an illustration from a I674 translation of Johannes Scultetus' The Chyrurgeon's Store-House (originally Armamentarium Chirurgiae, 1655), in which the images marked I to IV show the mastectomy operation. While the styles of these two representations are markedly different, certain aspects of their presentation are strikingly similar. In Scultetus' image as in Bulwer's, the intact breast is revealed, with the figure's clothing draped suggestively around the waist as if in the act of disrobing, though in Scultetus' image the flowing locks and jewellery which suggest a continuing feminine identity are absent. The faces of these figures, like those of Bulwer's Amazons, are blank despite the pain which is evidently being inflicted in Scultetus' image. The repetition of the figure in Scultetus' image has more explanatory value than in Bulwer's, but the urge to itemise the body is the same, even to the extent of showing the amputated breast. Correspondingly, the quasi-divine power of the disembodied hands descending into the scene, as if from heaven, describes a surgical power of remaking which is akin to the classificatory power of the ethnographer. As I will discuss below, people living with one-breasted bodies were under-represented on stage and in text. However, when such bodies could be viewed at a remove - within the confines of an

\footnotetext{
27 Alanna Skuse, 'Wombs, Worms and Wolves: Constructing Cancer in Early Modern England', Social History of Medicine 27:4 (2014): 632-48.

${ }_{28}$ On the gendering of cancer, see Skuse, Constructions of Cancer in Early Modern England, pp. 40-6o.
} 


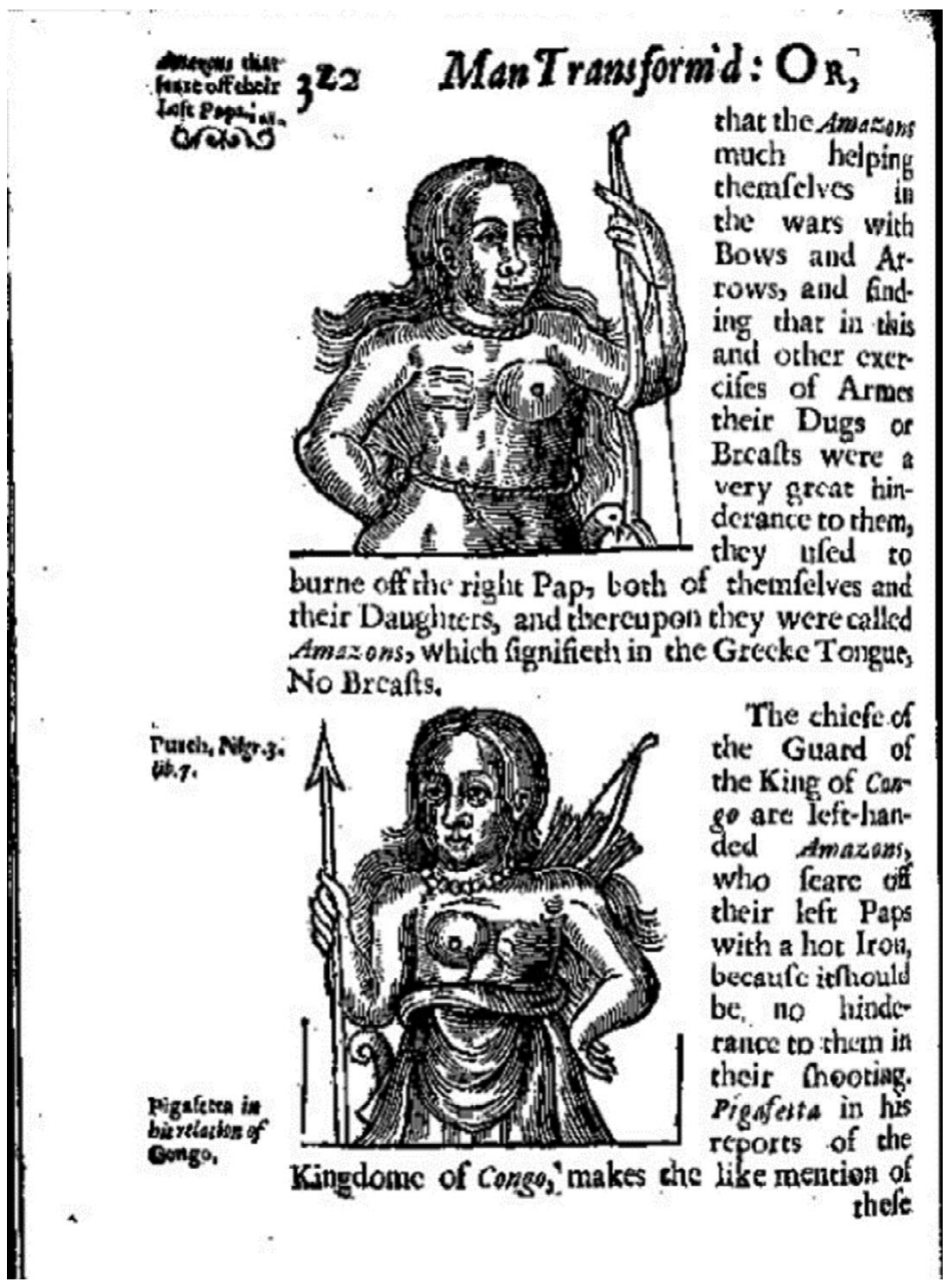

Figure 2.I Detail from John Bulwer's Anthropometamorphosis: = Man Transform'd: Or, the Artificiall Changling (London, I653).

Image produced by ProQuest as part of Early English Books Online (EEBO) www.proquest.com 


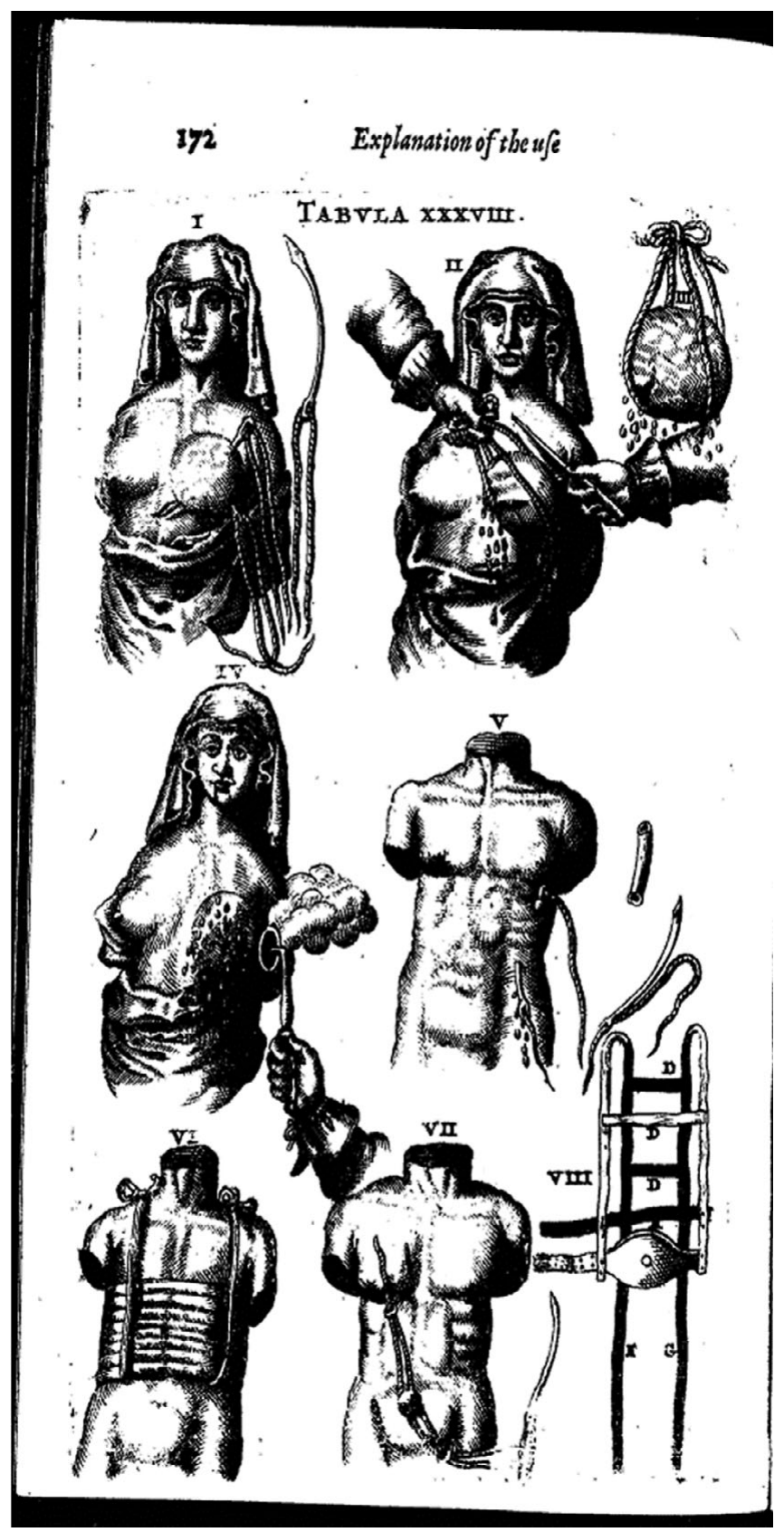

Figure 2.2 Detail from Johannes Scultetus, The Chyrurgeons Store-House (London, I674). Image produced by ProQuest as part of Early English Books Online (EEBO) www.proquest.com 
ethnographic or medical text - they drew on a shared visual language in which the altered female body was both a desirable and a fearful object.

We might then read the unimammarian Amazon body and the body of the mastectomy survivor in parallel. In Amazons, one-breastedness was an effect of a society in which maternity took a back seat to martial valour; it was, as Bulwer asserted, the physical means of 'discarding the tendernesse of their Sexe'. ${ }^{29}$ Gail Kern Paster similarly recognises,

Mastectomy ... implies the Amazon's crucial bodily heresy at least by comparison with the many claims, material and symbolic, on womb and breast in early modern culture - the heresy visibly to control their own bodies, to regulate their own reproductivity, and to offer a model of selfgovernment in which reproduction and nurture are only two of several forms of service and productive activity. ${ }^{30}$

While Amazons did not necessarily shun motherhood, they were commonly said to give their male children to others to raise. The Amazon's willingness to relinquish some of her maternal capacity, and some of her children, may have resonated with critics of wet-nursing, who saw the practice as indicating an unnatural paucity of maternal instinct. ${ }^{3 \text { I }}$ Meanwhile, the survivor of medical mastectomy was an unwilling participant in 'gestating' the tumour which might kill her, and which she attempted to expel through the painful and life-threatening experience of surgery. This sinister inversion of the process of pregnancy and birth was often bound up with perceived failure in or unwillingness to breastfeed one's child, though writers stopped short of blaming women for their illness. Whether early modern people perceived these similarities, and how that perception might have affected the experiences of mastectomy survivors, is opaque. No accounts of cancer surgery, medical or otherwise, make the link between the altered body of the mastectomy survivor and the Amazon. Nonetheless, I shall argue that this absence may itself say something about the way in which altered female bodies were placed - or displaced - in early modern culture.

\section{Abject Alteration}

As I have described, early modern ethnographic texts usually highlighted the Amazons' altered bodies. Amazon one-breastedness was strongly

\footnotetext{
29 Bulwer, Anthropometamorphosis, p. 323.

30 Gail Kern Paster, The Body Embarrassed: Drama and the Disciplines of Shame in Early Modern England (New York: Cornell University Press, I993), p. 237.

3r Jacques Guillemeau, Childbirth, or, the Happy Delivery of Women (London, I6 2 2).
} 
indexed to sexual freedom and a gynocentric way of living. The anxieties over maternity and sexuality Amazons provoked were also relevant to the bodies of early modern mastectomy survivors, though their exact relationship was unclear. In order to understand more about how images of the Amazon body might have impacted on the lived experiences of mastectomy survivors, I argue that one needs to look not only at those texts in which Amazon one-breastedness is present, but at those in which it is curiously and conspicuously absent.

Sexually altered female bodies were automatically excluded from many of the literary forms in which altered male bodies appeared. Unimammarian bodies were not deemed aesthetically useful in the same way as gelded male bodies. Hence, while castrati dominated the pages of newspapers and periodicals, Amazons were largely forgotten. Amazons did appear, however, in several seventeenth-century dramas, and in these plays, the missing breast is just that - missing. The absence is particularly striking when one considers early modern audiences' love of stage effects such as crutches, limps, and what Farah Karim-Cooper describes as 'the spectacle of dismemberment'. ${ }^{32}$ The image of a one-breasted woman, with the site of her mastectomy bared, would seem at first to be a gift to cross-dressing boy actors, who might utilise their naturally flat chests in the service of theatrical realism. One would imagine, too, that the missing breast would be a boon to playwrights, who so keenly played on the ideas of missing parts and no-thingness implied by the Amazon's correlate, the eunuch. Yet neither of these possibilities is realised. Shakespeare's Hippolyta, for instance, makes no mention of bodily difference, and neither does her husband-to-be, Theseus. ${ }^{33}$ John Weston's 1667 The Amazon Queen makes much of the Amazons' sexual freedom, but neither the women nor their lovers mention their having one breast. ${ }^{34}$ Moreover, John Fletcher and Philip Massinger'sThe Sea Voyage (I622) features an unspecified desert island populated by 'Amazons' who fulfil their ethnographic stereotypes by eschewing male authority while taking the play's shipwrecked male protagonists as temporary lovers. These women are said to be 'shaped like Amazons' in their social and sexual habits, but again, there is nothing in

${ }^{32}$ Farah Karim-Cooper, The Hand on the Shakespearean Stage: Gesture, Touch and the Spectacle of Dismemberment (London: Bloomsbury, 2016) pp. 197-24I. On the cultural and religious significance of dismemberment, see Chapters 4 and 5, below.

${ }^{33}$ For a perceptive discussion of Hippolyta's narrative functions, see Schwarz, Tough Love, pp. $205-10$.

34 John Weston, The Amazon Queen, or, The Amours of Thalestris to Alexander the Great (London: printed for Hen[ry] Harrington, 1667). 
the text to suggest that they are one-breasted (5.4.44). ${ }^{35}$ Furthermore, by the end of this play, the 'Amazons' are reunited with the husbands they thought had been lost at sea, and traditional - that is, patriarchal domesticity is restored.

These are all dramas in which the unimammarian body supposedly associated with Amazon women is quietly sidelined. On occasion, however, the omission of one-breastedness from representations of the Amazon on stage becomes positively conspicuous. In Jasper Maynes' I648 The Amorous Warre, which features supposedly historical Amazons including the queen Thalestris, the play's protagonists sleep with what they believe are Amazons, only to later discover that they have in fact been tricked into 'cheating' with their own wives. The men have explicitly evaded an encounter with unimammarian women, and their response highlights the distinct lack of such bodies on stage:

Theag[ines]: In my opinion, my Lord, these are

The strangest Amazons that ever left

Their female countrey for the use of men.

How did you find yours? Mine had breasts.

Mel[eager]: Troth mine, I thinke hath scap't the rasour too; I had

No leisure to examine parts. I found

No defects in her; But methought she was

To me a whole and perfect woman; I'm sure

She found me an entire and perfect man. ${ }^{36}$

Meleager's assurance that his bed partner found him 'entire' again hints at the possibility of male castration as an equivalent to female mastectomy, a threat which is raised by the thought of an anomalous female body and must be dismissed along with it. The invocation of the razor here as the instrument of mastectomy is perhaps significant, since this device was associated with both surgical procedures and with the removal of that masculine appendage, the beard. However, the integrity of the male protagonists' partners is stressed - they assuredly had breasts, had escaped the razor, and were whole and perfect. It appears that while missing arms and legs may be staged, and missing testicles may be heard of, if not seen, missing breasts are outside the realms of dramatic possibility.

The reluctance of early modern playwrights to stage the Amazon unimammarian body may be partly a facet of the general absence of

35 John Fletcher and Philip Massinger, 'The Sea Voyage', in Three Renaissance Travel Plays, ed. Anthony Parr (Manchester: Manchester University Press, I995), pp. I35-216.

${ }^{36}$ Jasper Mayne, The Amorous Warre (London: S.N., I648), pt. 5.I. 
America and its peoples from the early modern stage which has been observed by Gavin Hollis. In his book on the subject, Hollis notes that early modern plays rarely discuss the possibilities offered by European colonisation of America, and even less frequently frame those possibilities in positive terms, despite the concerted efforts of the Virginia Company's 'promotional machine'. ${ }^{37}$ Since Amazons were often believed to hail from Guiana, they came under the 'American' umbrella, and as elsewhere in this book, issues of gender, disability, and race intersect to render the body Other along multiple registers. Nonetheless, I contend that the determined inattention paid to Amazon one-breastedness on stage also reflects discomfort about altered female bodies in general. Viewed alongside the refusal of medical writers to discuss the anomalous bodies of mastectomy survivors, these Amazon absences indicate that early modern audiences had a problem with viewing sexually altered women 'in the flesh'. Ethnographic accounts of Amazons benefited from the conceptual distance imposed between readers and people who were clearly racial and social Others, even to the extent of explicitly picturing the one-breasted body. However, to imagine the site of mastectomy was horrifying when it was closer to home, that is, when it was presented on stage, or related to 'real' cancer surgeries. Though other kinds of bodily difference were certainly underrepresented and misrepresented in early modern texts, this reluctance to picture the results of surgical alteration was particular to breast amputation. Moreover, the effect of such omission was to deny the subjectivity and continued narrative of the mastectomy survivor. As Sarah Covington notes of early modern ex-soldiers, 'scars .... were corporal evidence of healing as well as damage - a memorializing faultline on the body that reminded the veteran of the "before" and "after" that his life had taken upon the injury he suffered'. ${ }^{38}$ The denial of the mastectomy scar precludes any possibility of 'memorializing' the female experience in the same way.

What made these altered bodies so different from others? Modern 'psycho-oncological' studies tracing women's experiences of cancer recognise that removing the breast has unique social significance. Mastectomy, it is argued, excludes women from a patriarchal culture in which their participation is always contingent and fragile:

37 Gavin Hollis, The Absence of America: the London Stage, I576-I642 (Oxford: Oxford University Press, 2015), p. 4.

${ }^{38}$ Sarah Covington, Wounds, Flesh, and Metaphor in Seventeenth-Century England (Basingstoke: Palgrave Macmillan, 2009), p. 86. 
Women's bodies occupy culturally liminal positions as part of cultural contexts that value women for their bodily appearances and their sexual desirability to men. In the present study, the liminal position of the women's bodies was demonstrated through accounts of the abject postcancer body, demonstrating difficulties in making meaning and 'placing' women's bodies within the symbolic order, as well as experiences of horror and repulsion toward the body ... Many of the women reported ... becoming invisible to the male gaze and having less value in terms of sexual attractiveness and beauty. ${ }^{39}$

In other words, there is no clear place for the non-breasted or one-breasted woman in a culture which commonly deems that feature unattractive, and which indexes attractiveness to social value. Early modern and modern perceptions of beauty do not always correlate, and as I have detailed elsewhere, the early modern breast signified in culturally specific ways. ${ }^{40}$ Arguably, the close physiological connection between lactation and menstruation which was prevalent in early modern medicine made breasts a somewhat problematic site of eroticism. ${ }^{4 \mathrm{I}}$ Nonetheless, mastectomied Amazonian bodies might likewise have been excluded from view because it was simply too difficult to square the sexual titillation offered by exotic half-naked women with the perceived unattractiveness of a missing breast.

While this observation goes some way to explaining the absence of onebreasted Amazons on stage, it does not fully account for the silence that surrounds recovery from mastectomy in other kinds of early modern text. To do so, we need to consider again the subject/object status of the body. Early modern lived experience, as this book will demonstrate, entailed intersubjectivity. ${ }^{42}$ However, it also required as its ground a distinct 'self which could be said to act, sense, and have experiences; in other words, to

39 Chloe M. Parton, Jane M. Ussher, and Janette Perz, 'Women's Construction of Embodiment and the Abject Sexual Body after Cancer', Qualitative Health Research 26:4 (2016): 500, https://doi.org/ I0.II77/I0497323I5570130. See also Dennis D. Waskul and Pamela van der Riet, 'The Abject Embodiment of Cancer Patients: Dignity, Selfhood, and the Grotesque Body', Symbolic Interaction 25:4 (2002): 487-5I3, https://doi.org/IO.I525/si.2002.25.4.487. For an overview of work on disability and feminism, see Anita Silvers, 'Feminism and Disability', in The Blackwell Guide to Feminist Philosophy, ed. Linda Martín Alcoff and Eva Feder Kittay (Oxford: Blackwell, 2007), pp. I 3 I-42, https://doi.org/IO.I002/9780470696I32.ch7.

40 Skuse, Constructions of Cancer in Early Modern England, pp. 45-53. ${ }^{41}$ Ibid., pp. 45-7.

42 There has been much work on the importance of relationships and communities in constituting early modern identities: see, for example, Margreta de Grazia, Maureen Quilligan, and Peter Stallybrass, eds., Subject and Object in Renaissance Culture (Cambridge: Cambridge University Press, I996); James Kuzner, Open Subjects: English Renaissance Republicans, Modern Selfhoods, and the Virtue of Vulnerability (Edinburgh: Edinburgh University Press, 20 I I); Christopher Tilmouth, 'Passion and Intersubjectivity in Early Modern Literature', in Passions and Subjectivity in Early Modern Culture, ed. Freya Sierhuis and Brian Cummings (Farnham: Ashgate, 2013), pp. I3-32. 
relate to the 'outside world' requires an 'inside' identity, even when that identity is itself materially grounded. To understand why the self-other distinction may be threatened by mastectomy, it is useful to turn to Julia Kristeva's Powers of Horror (1980). Drawing on Lacanian psychoanalysis, Kristeva identifies as 'abject' those things or phenomena which undermine our sense of physical and psychic integrity. The abject is that which 'disturbs identity, system, order. What does not respect borders, positions, rules. The in-between, the ambiguous, the composite. ${ }^{43}$ Witnessing the permeability of the bodily envelope through the abject is profoundly disturbing to one's sense of one's own subjectivity, as Josh Dohmen summarises:

Kristeva introduces the concept of abjection to offer a pre-Oedipal account of splitting that must occur before the formation of a stable subject and its stable objects. Whereas an object reveals the subject's detachment and autonomy, ' $[t]$ he abject has only one quality of the object - that of being opposed to I' ... The abject is a nonobject splitting from (but never completely split from) the subject-to-be. ${ }^{44}$

Read in this way, the mastectomied body is 'abject' along multiple registers. Like any wounded body, the body after mastectomy displays to viewers the fragility of the boundary between life and death, and between the interior of the body and the outside world. On the most basic level, the mastectomy operation brought life and death into uncomfortably close proximity; it was arguably even more dangerous than a limb amputation, so much so that many surgeons shunned the operation in favour of palliative care. ${ }^{45}$ Moreover, the unimammarian body is abject not only because it is hurt but also because it makes visible the material relations between one body and another. That is, by removing one breast, attention is drawn to the nutritive function of the remaining breast, and thus to the state of infancy in which mother and child are imperfectly separated. As Ashley Denham Busse explains:

in Kristeva's analysis the maternal function comes to stand in not only for the subject's pre-Symbolic existence in its imagined wholeness but also for all that which must be cast aside continually in order for the subject to exist, that is, any reminder of one's material origins or mortality. What results is

\footnotetext{
${ }^{43}$ Julia Kristeva, Powers of Horror: An Essay on Abjection, trans. Leon S. Roudiez (1980; New York: Columbia University Press, I982), p. 4.

44 Josh Dohmen, 'Disability as Abject: Kristeva, Disability, and Resistance', Hypatia 3 I:4 (2016): 768 , https://doi.org/IO. I I I /hypa.I 2266.

45 Skuse, Constructions of Cancer in Early Modern England, p. I27.
} 
an erotic ambivalence, a desire and fascination for the (maternal) body as well as a fear of its power to annihilate. ${ }^{46}$

The positioning of the altered female body as abject is recognised by modern psycho-oncology, with Parton et al. describing how women after mastectomy felt 'outside normality', such that 'discursive resources were limited for capturing embodied experiences, and ... the women's subject positioning subsequently became unsettled and fragile'. ${ }^{47}$ In an early modern context, this effect is heightened by the longstanding association of women's bodies (healthy or otherwise) with abjection. While they do not employ Kristeva's overtly psychoanalytic methodology, historicist readings of early modern drama have broadly agreed that the functions of the lactating, menstruating, leaky female body persistently troubled playwrights and authors. ${ }^{48}$ The illimitability of the female body was suspected to pervade everyday life, from the effects of maternal imagination on a growing foetus to the menstruating woman's ability to curdle milk with a glance. ${ }^{49}$ Furthermore, the classification of anomalous female bodies as abject follows what Schwarz describes as the 'familiar pattern of abjection, which consolidates the center by exacting its price from the margins. ${ }^{50}$ Making the anomalous female body marginal repositions maleness and able-bodiedness as normal, makes male sexual desire the criterion for social acceptability, and quells perceived threats to this 'normality' posed by Amazon women who elude heteronormative social structures and accepted definitions of 'ability'. ${ }^{\text {I }}$ This is, as Schwarz observes of Shakespeare's dead female characters, an easier project to fulfil when the troublesome women in question are deceased, since 'death might

${ }^{46}$ Ashley Denham Busse, "QQuod Me Nutrit Me Destruit": Discovering the Abject on the Early Modern Stage', Journal of Medieval and Early Modern Studies 43:I (20I3): 73, https://doi.org/ IO .I215/10829636-1902549.

47 Parton et al., 'Women's Construction of Embodiment and the Abject Sexual Body after Cancer', 493. On abjection as a means for theorising disability (including the limitations of such an approach), see Bill Hughes, 'Wounded/Monstrous/Abject: A Critique of the Disabled Body in the Sociological Imaginary', Disability and Society 24:4 (2009): 399-4Io, https://doi.org/I0.I080/ 09687590902876 I 44 .

${ }^{8}$ Paster, The Body Embarrassed.

49 Mary Elizabeth Fissell, Vernacular Bodies: The Politics of Reproduction in Early Modern England (Oxford: Oxford University Press, 2004), p. 208; Patricia Crawford, 'Attitudes to Menstruation in Seventeenth-Century England', Past and Present 9i (I98 I): 46-73.

so Kathryn Schwarz, 'Death and Theory: Or, the Problem of Counterfactual Sex', in Sex before Sex: Figuring the Act in Early Modern England, ed. James M. Bromley and Will Stockton (Minneapolis: University of Minnesota Press, 2013), p. 58.

5I For an interesting discussion of abjection and the male subject, see Catherine Bates, Masculinity, Gender and Identity in the English Renaissance Lyric (Cambridge: Cambridge University Press, 2007), especially pp. I36-73. 
fix a particular condition of worth; whether necrophilic or necrophobic, history digests its victims in the service of its authors'. ${ }^{52}$ While not necessarily dead, the abjection of one-breasted women seems to follow the same principle: marginalising and repudiating bodies works better when those bodies are not around to assert themselves as subjects. Nonetheless, the very need for repudiation implies a continuing blurring of boundaries; as Schwarz argues, 'Attempts to fix a particular condition of worth collide with the polyvalence of that counterfactual "what if?" 53 The threat posed by abjection is never extinguished because the project of repudiating the abject is always incomplete. Thoughts of mastectomy crept into early modern plays even as the characters insisted that their partners 'had breasts', revealing a fascination with the twin qualities of maternity and death evoked by the one-breasted body.

When the maternal body met the altered body, then, the result was more unpalatable than intriguing, since to look upon this body was to risk a collapse of personal identities. Jokes could not be made about mastectomy as they were about castration or limb loss. Amazons might be imagined as vocal and powerful on stage, but only if the matter of their altered body was suppressed. Furthermore, in this respect art imitated life. While numerous medical texts gave instructions for mastectomy operations, and a few supplied accounts thereof, details about the lives of women after mastectomy are, remarkably, entirely absent from early modern writing of all kinds. This book will show early modern texts populated by amputees, prosthesis users, and people with 'altered bodies' of all kinds. Mastectomy survivors are not in those texts.

\section{Conclusion}

In I734, a letter written to the editor of The Prompter, complaining about castrati, suggested an extraordinary means of resolving the 'opera problem':

Mr Prompter, if all your Attempts to pull down Operas, and get rid of these Monsters [castrati], should prove ineffectual, I have a Thought come into my Head, that I believe will not fail. Indeed, I scarce dare communicate it, but when the publick Good is in View, nothing shou'd hinder a Man. It is this then, for I must tell you; Suppose we should castrate, or qualify, our Women, as they do their Men in Italy ... 'Tis plain, that in this way those Shoals of Females that wander about the Town, quite useless for want of Husbands or Lovers, might be made very serviceable to the Publick, by so

\footnotetext{
52 Schwarz, 'Death and Theory', p. $58 . \quad 53$ Ibid., p. 59.
} 
considerable an Improvement of Operas. But I find I am got a little beside my Purpose. For I propose the thing, because I am assured it clears the Voices of Girls, as well as Boys. And since Women have naturally shriller and sweeter Pipes than Men, if the artificial Improvement shou'd be but equal, it will be an angelical Charm to hear them. ${ }^{54}$

Clearly, this letter-writer was not in earnest. The Prompter was a publication whose main concern was satirising and gossiping about the theatre and its inhabitants, not proposing experimental surgeries. ${ }^{55}$ Yet, the outraged author had not pulled their suggestion from thin air. The sterilisation of women had been mooted before, in the same texts in which Amazonian mastectomy was described, and like this practice (and like some kinds of eunuchism), female sterilisation was believed to have originated in Africa and the Middle East. The I658 Rare Verities, for instance, attested that

It's a far harder matter to Eunuchize women [than men], yet in former and latter times it hath been accomplished. Antonius Ulmus saith it may be done by cutting the Nympha, which is the throne of love and lust. Thus many of the Egyptian women have been used by reason of their untamed lust. Now properly to castrate a woman, is to take out her womb, for the doing of which, since it is so hard and dangerous, I dare not give any directions. ${ }^{56}$

The Oxford English Dictionary suggests that 'nympha' in this period referred to labia minora; this author clearly believed that their removal would impede female sexual pleasure, though an internal operation was required to truly sterilise the female patient. John Bulwer's Anthropometamorphosis (1653) and Nicholas Venette's Mysteries of Conjugal Love ( 1707 ) both similarly suggested that female castration might have been undertaken in the ancient world or more recently in Africa and the Middle East. ${ }^{57}$ Again, both questioned how the operation could have been completed without killing the patient. Venette suggested that the 'castration' had in fact been a kind of chastity belt, or perhaps the stitching up of the women's 'privities'. Bulwer, however, took a more credulous view:

54 'Letter to the Editor', Prompter, I9 December I735.

55 Kalman A. Burnim, 'Aaron Hill's "The Prompter": An Eighteenth-Century Theatrical Paper', Educational Theatre Journal I 3:2 (I96I): 73-8I.

56 Giovanni Benedetto Sinibaldi, Rare Verities (London: P. Briggs, I658), pp. 50-I.

57 Bulwer, Anthropometamorphosis, pp. 363-4; Nicholas Venette, The Mysteries of Conjugal Love Reveal'd Written in French by Nicholas de Venette, ... The 8th Edition. Done into English by a Gentleman, 2nd edition (London, I707), pp. 495-6. 
For he must necessarily cut both the flankes who would castrate a woman, a worke full of desperate hazzard; yet it may be done with little or no danger, if it be attempted with an artfull hand. And a Friend of mine told me he knew a maid in Northampton-shire that was thus spaded by a sow-gelder, and escaping the danger grew very fat. ${ }^{58}$

Stories about the sterilisation of women were exceedingly rare, much rarer than those about Amazons. Nonetheless, the terms in which such tales were framed underline how ethnography functioned as a way of thinking about different kinds of bodily change, whilst keeping the physical and social implications of bodily alterity safely at arm's length. They also demonstrate how sex-specific alterations to the female body were consistently indexed to the illimitability of female desire. By forcing a comparison between castrati and neutered women, the Prompter's letterwriter actually demonstrated their non-equivalence. Despite his feigned naivety, the author knows that spayed women cannot have an instrumental value like that of castrati. Eliminating the risk of pregnancy for women who wander the streets creates a different kind of commodified body: not opera stars, but prostitutes.

'Spayed' and unimammarian female bodies functioned similarly to provoke conflicted reactions in the (overwhelmingly male) authors by whom they were described. On one hand, it is clear that such bodies were a source of fascination, and sometimes of titillation. On the other, surgical changes to the female body - especially when focussed on sexual characteristics - were a cause for anxiety. Wounds, even when healed, showed the permeability and impermanency of the bodily envelope. Female bodies likewise threatened illimitability and unboundedness. The combination of the two was therefore experienced as a threat to personal identity. Furthermore, this threat was experienced more profoundly because, as the following chapters will show, early modern models of embodiment were unfixed, often dwelling on indeterminacy and change. In this climate, stories of surgically altered bodies were almost always stories of male bodies. The phenomenological experiences of surgically altered women were obfuscated and ignored in order to maintain the distinction between 'self and 'other' on which authors' and audiences' sense of subjective identity depended.

58 Bulwer, Anthropometamorphosis, p. 364. 